\title{
Purification and partial characterization of thiosulphate dehydrogenase from Thiobacillus acidophilus
}

\author{
Rogier Meulenberg, Jack T. Pronk, * Wim Hazeu, Johannes P. van Dijken, \\ Johannes Frank, Piet Bos and J. Gijs Kuenen
}

Department of Microbiology and Enzymology, Kluyver Laboratory for Biotechnology, Delft University of Technology, Julianalaan 67, 2628 BC Delft, The Netherlands

(Received 11 February 1993; revised 12 May 1993; accepted 27 May 1993)

\begin{abstract}
Thiosulphate dehydrogenase (EC 1.8.2.2; thiosulphate:acceptor oxidoreductase) was purified to apparent homogeneity from Thiobacillus acidophilus by a combination of ammonium sulphate precipitation, hydrophobic interaction chromatography, anion-exchange chromatography and gel filtration. The enzyme catalysed the oxidation of thiosulphate $\left(\mathrm{S}_{2} \mathrm{O}_{3}^{2-}\right)$ to tetrathionate $\left(\mathrm{S}_{4} \mathrm{O}_{6}^{2-}\right)$ with potassium ferricyanide as an artificial electron acceptor. The molecular mass of the native enzyme, as determined by gel filtration, was $102 \pm 4 \cdot 2 \mathrm{kDa}$. The enzyme contained two different subunits with a molecular mass of $24 \pm 0.9$ and $20 \pm 1.0 \mathrm{kDa}$ (SDS-PAGE), respectively. Both subunits contained $c_{553}$-type haem with absorption bands at 553, 524 and $416 \mathrm{~nm}$. A $77 \mathrm{~K}$ spectrum of purified thiosulphate dehydrogenase revealed that the absorption at $553 \mathrm{~nm}$ is due to different haem groups. A cytochrome content of 5.3 mole $c$-type haem per mole of native enzyme was calculated. The pH optimum of the purified enzyme was 3. Apart from ferricyanide, Wurster's blue (the free radical of tetramethyl p-phenylenediamine) and horse heart cytochrome $c$ could also serve as electron acceptors, though less effectively than ferricyanide. At $\mathrm{pH} 7.0$, the $K_{\mathrm{m}}$ for thiosulphate was $0.54 \mathrm{mM}$. The $K_{\mathrm{m}}$ could not be determined at the $\mathrm{pH}$ optimum due to the chemical reactivity of thiosulphate at low $\mathrm{pH}$ values. Sulphite was a potent inhibitor of enzyme activity.
\end{abstract}

\section{Introduction}

Despite its economic and environmental importance, knowledge about the enzymology of inorganic sulphur oxidation by acidophilic Thiobacillus species is incomplete (for a review see Pronk et al., 1990a). Studies with the obligate autotrophs $T$. ferrooxidans and $T$. thiooxidans (Sinha \& Walden, 1966; Okuzumi \& Kita, 1965) and the facultative autotroph T. acidophilus (Meulenberg et al., 1992a) indicated that the initial step in the metabolism of thiosulphate $\left(\mathrm{S}_{2} \mathrm{O}_{3}^{2-}\right)$ by these bacteria is its oxidation to tetrathionate $\left(\mathrm{S}_{4} \mathrm{O}_{6}^{2-}\right)$. Thiosulphate dehydrogenase (EC 1 8.2.2), the enzyme catalysing this reaction, has been partially purified from $T$. ferrooxidans by Silver \& Lundgren (1968). In the acidophilic thiobacilli, thiosulphate dehydrogenase is probably a periplasmic enzyme, exposed to low $\mathrm{pH}$ values (Pronk et al.,

\footnotetext{
* Author for correspondence. Tel. 15782387 ; fax 15782355.

Abbreviations: DCPIP, dichlorophenol indophenol; MTT, methy]thiazol tetrazolium bromide, PES, phenazine ethosulphate; PMS, phenazine methosulphate; PQQ, pyrrolo-quinoline quinone.
}

1990 a). However, no data are available on the catalytic activity of this enzyme at $\mathrm{pH}$ values below 4.5 .

The aim of the present study was the purification and characterization of thiosulphate dehydrogenase from cell extracts of $T$. acidophilus, with special emphasis on product formation and enzyme characteristics at low $\mathrm{pH}$.

\section{Methods}

Organism and growth conditions. T. acidophilus DSM 700 was maintained as described previously (Pronk et al., 1990b). Mixotrophic chemostat cultures were used for production of biomass and were grown as described by Meulenberg et al. (1992a).

Enzyme assay. The standard reaction mixture $(1 \mathrm{ml})$ for assays at neutral $\mathrm{pH}$ contained $25 \mathrm{mM}-\left(\mathrm{NH}_{4}\right)_{2} \mathrm{SO}_{4}(\mathrm{pH} 7.0), 0.9 \mathrm{mM}-\mathrm{K}_{3} \mathrm{Fe}(\mathrm{CN})_{6}$ and cell extract. After $2 \mathrm{~min}$ equilibration at $30{ }^{\circ} \mathrm{C}$, the reaction was started by the addition of $5 \mathrm{~mm}-\mathrm{Na}_{2} \mathrm{~S}_{2} \mathrm{O}_{3}$. For determination of enzyme activity at lower $\mathrm{pH}$ values, the $\mathrm{pH}$ of the $\left(\mathrm{NH}_{4}\right)_{2} \mathrm{SO}_{4}$ buffer was adjusted with $\mathrm{H}_{2} \mathrm{SO}_{4}$ and the reaction was started with $0.2 \mathrm{~mm}$ thiosulphate. Reduction of ferricyanide was measured at $420 \mathrm{~nm}$ in a spectrophotometer (Hitachi 100-60), using an extinction coefficient of $0.9 \times 10^{3} \mathrm{M}^{-1} \mathrm{~cm}^{-1}$. Initial reaction rates were proportional to the amount of enzyme added. Activities were expressed as units (mg protein $)^{-1}: 1 \mathrm{U}$ is defined as the amount of enzyme catalysing the reduction of $1 \mu \mathrm{mol}$ ferricyanide $\mathrm{min}^{-1}$.
} 


\section{Enzyme purification}

To avoid protein precipitation, which occurred at $\mathrm{pH} 5$ and below, enzyme purification and activity measurements after each purification step were performed at $\mathrm{pH} 7$. Enzyme purification was performed at room temperature, except for the ammonium sulphate precipitation, which was carried out on ice. Fractions containing activity were frozen and stored in liquid nitrogen. Solutions for activity measurements and enzyme purification were prepared and stored in disposable plastic labware.

Cell disruption. Cells (10 g dry mass) were suspended in $100 \mathrm{ml}$ of culture supernatant adjusted to $\mathrm{pH} 7$. Cells were passed twice through a French pressure cell (Aminco) at $110 \mathrm{MPa}$ and centrifuged (20 min at $48000 \mathrm{~g}$ ). The pellet was extracted three times with $60 \mathrm{ml}$ of culture supernatant adjusted to $\mathrm{pH} 7.0$. All extracts were pooled and again centrifuged ( $20 \mathrm{~min}$ at $48000 \mathrm{~g}$ ). The resulting supernatant was used for further purification steps.

Ammonium sulphate precipitation. $\left(\mathrm{NH}_{4}\right)_{2} \mathrm{SO}_{4}$ was added to the enzyme solution to a concentration of $3.0 \mathrm{M}$. Precipitated protein was centrifuged ( $40 \mathrm{~min}$ at $48000 \mathrm{~g}$ ), redissolved in $50 \mathrm{ml} 25 \mathrm{~mm}$-sodium

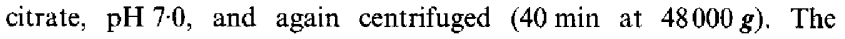
supernatant was used for further purification.

Hydrophobic interaction chromatography. Hydrophobic interaction chromatography was performed with a phenyl-sepharose column (HiLoad XK 26, HR 26/10, Pharmacia) combined with a Pharmacia FPLC system (described by Meulenberg et al., 1992b). After addition of $\left(\mathrm{NH}_{4}\right)_{2} \mathrm{SO}_{4}$ to a concentration of $1.5 \mathrm{M}$ and centrifugation (30 min at $48000 \mathrm{~g}$ ), enzyme solution was loaded on the column, equilibrated with 25 mM-sodium citrate $+1 \cdot 5 \mathrm{M}-\left(\mathrm{NH}_{4}\right)_{2} \mathrm{SO}_{4}(\mathrm{pH} 7 \cdot 0)$. The column was eluted with equilibration buffer at a flow rate of $3.0 \mathrm{ml} \mathrm{min}{ }^{-1}$ until the $A_{280}$ of the eluent was below $0 \cdot 2$. A linear gradient $(560 \mathrm{ml})$ of 1.5 to $0 \mathrm{M}-\left(\mathrm{NH}_{4}\right)_{2} \mathrm{SO}_{4}$ in $25 \mathrm{~mm}$-sodium citrate $(\mathrm{pH} 7 \cdot 0)$ was then applied at the same flow rate. Fractions containing enzyme activity were pooled, concentrated and desalted to a final $\left(\mathrm{NH}_{4}\right)_{2} \mathrm{SO}_{4}$ concentration of $25 \mathrm{mM}$ (Centriprep-30, Amicon).

Anion-exchange chromatography. Anion-exchange FPLC was performed with a Mono-Q column (HR 5/5, Pharmacia), equilibrated with $25 \mathrm{~mm}$-sodium citrate ( $\mathrm{pH} \mathrm{7.0)}$ ). After loading the enzyme solution on the column, the latter was washed with equilibration buffer at a flow rate of $0.5 \mathrm{ml} \mathrm{min}-1$ until the $A_{280}$ of the eluent was below 0.0005 . A linear gradient $(20 \mathrm{ml})$ of 0 to $1.0 \mathrm{M}-\mathrm{NaCl}$ in $25 \mathrm{~mm}$-sodium citrate $(\mathrm{pH} 7-0)$ was then applied at the same flow rate. Fractions containing enzyme activity were stored in liquid nitrogen.

Gel filtration. Final purification was performed by gel filtration on a Superose 6 column (HR 10/30, Pharmacia) combined with an HPLC system consisting of a Hitachi L-6210 intelligent pump and a Waters 991 photodiode-array detector. The column was equilibrated with $0.5 \mathrm{M}-\left(\mathrm{NH}_{4}\right)_{2} \mathrm{SO}_{4}(\mathrm{pH} 7.0)$ at a flow rate of $0.5 \mathrm{ml} \mathrm{min}{ }^{-1}$. Elution of protein was followed at $280 \mathrm{~nm}$ and spectra $(190-800 \mathrm{~nm})$ were recorded at $6 \mathrm{~s}$ intervals. Active fractions from successive injections were pooled, concentrated (Centricon-30, Amicon) and stored in liquid nitrogen.

$P A G E$. Analytical SDS-PAGE (PhastSystem, Pharmacia) was performed at room temperature according to Laemmli (1970), using an $8-25 \%(\mathrm{w} / \mathrm{v})$ gradient acrylamide resolving gel and a $4.5 \%(\mathrm{w} / \mathrm{v})$ acrylamide stacking gel. Purified thiosulphate dehydrogenase $(30 \mathrm{ng}$ ) was boiled for $5 \mathrm{~min}$ in a buffer containing $62.5 \mathrm{~mm}$-Tris, $50 \mathrm{~mm}$ dithiothreitol, $50 \mathrm{mM}-\beta$-mercaptoethanol, $10 \%$, w/v, glycerol, $2.5 \%$, $\mathrm{w} / \mathrm{v}$, SDS and $0.002 \%$ bromophenol blue, $\mathrm{pH} 6.8$. Electrophoresis was carried out with $30 \mathrm{ng}$ of purified enzyme. Protein was stained with the Bio-Rad silver staining kit. Haem-containing proteins were visualized with tetramethylbenzidine (Thomas et al., 1976).

Molecular mass. The apparent molecular mass of native enzyme was determined by gel filtration. The Superose 6 column was calibrated with $\alpha$-chymotrypsin from bovine pancreas ( $25 \mathrm{kDa}$, Sigma), ovalbumin (43 kDa, Pharmacia), bovine serum albumin $(67 \mathrm{kDa}$ and $134 \mathrm{kDa}$, Sigma), catalase (232 kDa, Pharmacia), ferritine ( $440 \mathrm{kDa}$, Pharmacia) and thyroglobulin ( $669 \mathrm{kDa}$, Pharmacia). Retention was plotted as $K_{\mathrm{av}}\left[=\left(V_{\mathrm{e}}-V_{0}\right) \cdot\left(V_{1}-V_{0}\right)^{-1} ; V_{\mathrm{e}}\right.$, retention volume of calibration proteins; $V_{0}$, void volume of the column; $V_{n}$, column volume] against the logarithm of the molecular mass. The molecular mass of denatured enzyme was determined by SDS-PAGE, calibrated with the Pharmacia low molecular mass electrophoresis calibration kit. For determination of molecular masses after haem-staining, a kit of pre-stained markers (Pharmacia) was used. Mobility of marker proteins relative to the electrophoresis front was plotted versus the logarithm of the molecular mass.

High resolution absorption spectra. Spectra of purified thiosulphate dehydrogenase were recorded on an Aminco DW-2000 (room temperature) and a DW-2 (77K) UV-Vis dual wavelength spectrophotometer (SLM Instruments).

Analytical procedures. Thiosulphate and tetrathionate concentrations were determined as described by Sörbo (1957). After cyanolysis, samples were centrifuged ( $10 \mathrm{~min}$ at $13000 \mathrm{~g}$ ) and absorption at $460 \mathrm{~nm}$ was measured. Protein concentrations were determined according to the method of Bradford (1976). For identification of the cytochrome type and content, the pyridine haemochromogen method (Rieske, 1967) was used, with horse heart cytochrome $c$ and a $b$-type cytochrome from Thiosphaera pantotropha as references. For calculation of the cytochrome content of native thiosulphate dehydrogenase, an extinction coefficient at $550 \mathrm{~nm}$ of $31.18 \times 10^{3} \mathrm{M}^{-1} \mathrm{~cm}^{-1}$ of pyridine haemochrome was used (Bartsch, 1971).

Discontinuous enzyme assay. Enzyme solution was incubated in a well-mixed, thermostated $\left(30^{\circ} \mathrm{C}\right)$ reaction chamber $(15 \mathrm{ml})$ containing $25 \mathrm{~mm}-\left(\mathrm{NH}_{4}\right)_{2} \mathrm{SO}_{4}(\mathrm{pH} \mathrm{3.0}), 1 \mathrm{~mm}-\mathrm{K}_{3} \mathrm{Fe}(\mathrm{CN})_{6}$ and $0.5 \mathrm{~mm}-\mathrm{Na}_{2} \mathrm{~S}_{2} \mathrm{O}_{3}$. Samples were taken at appropriate time intervals to determine thiosulphate and tetrathionate concentrations.

pH optimum, stability and kinetic constants. The $\mathrm{pH}$ optimum for enzyme activity was determined with the standard assay mixture, using 0.2 mm-thiosulphate. The $\mathrm{pH}$ of the assay buffer was adjusted with either $\mathrm{H}_{2} \mathrm{SO}_{4}$ or $\mathrm{KOH}$. The actual $\mathrm{pH}$ of the assay mixture was measured before addition of thiosulphate and did not change significantly during the reaction. The stability of thiosulphate dehydrogenase as a function of $\mathrm{pH}$ was studied at 0 and $30^{\circ} \mathrm{C}$. Purified enzyme was diluted in $25 \mathrm{~mm}-\left(\mathrm{NH}_{4}\right)_{2} \mathrm{SO}_{4}(\mathrm{pH} \mathrm{1} 10-7 \cdot 0)$ and incubated on ice or at $30^{\circ} \mathrm{C}$. At appropriate intervals, enzyme activity was assayed at $\mathrm{pH} 3.0$ and at $30^{\circ} \mathrm{C}$. Kinetic constants were determined at $\mathrm{pH} 7.0$ and at $30^{\circ} \mathrm{C} . K_{\mathrm{m}}$ and $V_{\max }$ were calculated by a non-linear least squares fit of the data according to the Michaelis-Menten model (software: Fig P 4. 1, Biosoft).

Substrate specificity and inhibitors. Substrate specificity was studied at $\mathrm{pH} 3.0$ and at $\mathrm{pH} 7.0$. Sodium sulphite $(0.5 \mathrm{~mm})$, sodium trithionate $(5 \mathrm{~mm})$ and potassium tetrathionate $(5 \mathrm{~mm})$ were tested as substrates. Sodium sulphide could not be tested since it reacted chemically with ferricyanide. The following alternative electron acceptors were tested at $\mathrm{pH} 7.0$ (wavelength and absorption coefficients are given in brackets): $0.05 \mathrm{~mm}$-dichlorophenol indophenol (DCPIP; $600 \mathrm{~nm} ; 16.3 \mathrm{mM}^{-1}$ $\mathrm{cm}^{-1}$ ), also tested in combination with $0.6 \mathrm{~mm}$-phenazine methosulphate (PMS) or $0.6 \mathrm{~mm}$-phenazine ethosulphate (PES), 0.1 mMWurster's blue (the free radical of tetramethyl $p$-phenylenediamine; Michaelis \& Gramick, 1943$)\left(600 \mathrm{~nm} ; 9 \mathrm{~mm}^{-1} \mathrm{~cm}^{-1}\right)$, $0.05 \mathrm{~mm}$-horse heart cytochrome $c\left(550 \mathrm{~nm} ; 19.6 \mathrm{~mm}^{-1} \mathrm{~cm}^{-1}\right), 0.06 \mathrm{mM}-$ cytochrome $c_{500}$ from Thiobacillus versutus $\left(550 \mathrm{~nm} ; 24 \mathrm{~mm}^{-1} \mathrm{~cm}^{-1}\right)$, 0.1 mM-methylthiazol tetrazolium bromide (MTT; $580 \mathrm{~nm} ; 13.0 \mathrm{mM}^{-1}$ $\left.\mathrm{cm}^{-1}\right), 0.2 \mathrm{~mm}$-benzyl viologen $\left(600 \mathrm{~nm} ; 14.7 \mathrm{~mm}^{-1} \mathrm{~cm}^{-1}\right), 0.2 \mathrm{mM}-$ methyl viologen $\left(600 \mathrm{~nm} ; 11.3 \mathrm{~mm}^{-1} \mathrm{~cm}^{-1}\right), 0.01 \mathrm{~mm}$-methylene blue 
$\left(650 \mathrm{~nm} ; 89 \mathrm{mM}^{-1} \mathrm{~cm}^{-1}\right), 0.2 \mathrm{~mm}-\mathrm{NAD}^{+}\left(340 \mathrm{~nm} ; 6.22 \mathrm{~mm}^{-1} \mathrm{~cm}^{-1}\right)$ and $0.2 \mathrm{~mm}-\mathrm{NADP}^{+}\left(340 \mathrm{~nm} ; 6.22 \mathrm{~mm}^{-1} \mathrm{~cm}^{-1}\right)$. Molecular oxygen $(0.236 \mathrm{~mm})$, also in combination with $0.3 \mathrm{~mm}-\mathrm{PMS} /$ catalase or $1.0 \mathrm{~mm}$ pyrrolo-quinoline quinone (PQQ)/catalase was tested using a biological oxygen monitor. If necessary, the observed reaction rates were corrected for the low chemical reaction rates occurring in the absence of enzyme. The effect of potential inhibitors was studied by preincubation for $2 \mathrm{~min}$ at $30^{\circ} \mathrm{C}$, after which activity was measured at $\mathrm{pH} 3 \cdot 0$.

Chemicals. Sodium trithionate was prepared as described by Wood \& Kelly (1986). Cytochrome $c_{550}$ from T. versutus and Wurster's blue were kind gifts from Ton Mulder and Barend Groen (Delft University of Technology). All other chemicals were of analytical grade and were obtained from commercial sources.

\section{Results}

Enzyme activity in cell-free extracts

Previous inhibitor studies suggested that oxidation of thiosulphate to tetrathionate by Thiobacillus acidophilus occurs in the periplasm and, consequently, that the enzyme catalysing this reaction is exposed to low $\mathrm{pH}$ values (Meulenberg et al., 1992a). However, when cell extracts were prepared in acidic ( $\mathrm{pH} \mathrm{3.0)}$ ) buffers, no thiosulphate dehydrogenase activity was found in the supernatant after centrifugation. At this low $\mathrm{pH}$, the enzyme apparently co-precipitated with cytoplasmic enzymes; sonication of the pellet of cell debris and precipitated proteins released small amounts of enzyme activity (results not shown). In contrast, cell extracts prepared at $\mathrm{pH} 7.0$ reproducibly oxidized thiosulphate to tetrathionate at neutral $\mathrm{pH}$ with stoichiometric reduction of ferricyanide.

\section{Enzyme purification}

The purification of thiosulphate dehydrogenase from $T$. acidophilus is summarized in Table 1. Before anion exchange, the enzyme solution had to be desalted. However, at ammonium sulphate concentrations below $100 \mathrm{~mm}$, the enzyme activity partially precipitated, which resulted in a low recovery after anion-exchange chromatography (Table 1). Since anion-exchange chromatography resulted in a substantial purification, this low recovery was accepted. When low-ionic-strength buffers were used for gel filtration, the enzyme activity was not adequately separated from contaminating proteins. However, when $0.5 \mathrm{M}$-ammonium sulphate was used as the elution buffer, thiosulphate dehydrogenase eluted as a single peak ahead of other proteins.

To check the purity of the final enzyme preparation, native gel electrophoresis was performed. However, for unknown reasons the enzyme did not migrate through the acrylamide gel. Some indication of the purity of the enzyme can be derived from the fact that, after a thousandfold purification, it produced only one single peak after gel filtration. The purity of that peak was assessed with the purity algorithm (Gorenstein et al., 1993) included in the Millenium 2010 Chromatography Manager, which compares all the spectra (from 250$600 \mathrm{~nm}$ ) taken in the peak. No impurities were detected in the central $95 \%$ of the peak.

\section{Physical properties}

SDS-PAGE of purified and denatured thiosulphate dehydrogenase revealed two different protein bands with molecular masses of $24 \pm 0.9$ and $20 \pm 1.0 \mathrm{kDa}$, respectively (not shown). From gel filtration, a molecular mass of $102 \pm 4.2 \mathrm{kDa}$ was calculated for the native enzyme. The absorption spectrum of purified thiosulphate dehydrogenase showed absorption maxima at 278, 416 (Soret-band), 524 ( $\beta$-band) and $553 \mathrm{~nm}$ ( $\alpha$-band) (Fig. 1), implying the presence of a $c_{553}$-type haem. The absorption maximum at $550 \mathrm{~nm}$ of the reduced pyridine haemochrome, extracted from thiosulphate dehydrogenase, confirmed that the enzyme contains a $c$-type cytochrome (data not shown) (Rieske, 1967). From this absorption maximum a cytochrome content of 5.3 moles of haem per mole of native enzyme could be calculated (Bartsch, 1971). Haem-staining of the two protein bands after denaturing SDS-PAGE indicated that both subunits

Table 1. Purification of thiosulphate dehydrogenase from $T$. acidophilus

Activities were determined using the standard enzyme assay.

\begin{tabular}{cccccc}
\hline \hline $\begin{array}{c}\text { Purification } \\
\text { step }\end{array}$ & $\begin{array}{c}\text { Total } \\
\text { protein } \\
(\mathrm{mg})\end{array}$ & $\begin{array}{c}\text { Total } \\
\text { activity } \\
(\mathrm{U})\end{array}$ & $\begin{array}{c}\text { Specific } \\
\text { activity } \\
\left(\mathrm{U} \mathrm{mg}^{-1}\right)\end{array}$ & $\begin{array}{c}\text { Recovery } \\
(\%)\end{array}$ & $\begin{array}{c}\text { Purification } \\
(-\mathrm{fold})\end{array}$ \\
\hline $\begin{array}{c}\text { Cell-free extract } \\
\text { Ammonium sulphate } \\
\text { precipitation }\end{array}$ & 1045 & 5025 & $4 \cdot 8$ & 100 & $1 \cdot 0$ \\
$\begin{array}{c}\text { Hydrophobic } \\
\text { interaction }\end{array}$ & 19 & 2570 & 135 & 51 & 28 \\
$\quad \begin{array}{c}\text { Anion exchange } \\
\text { Gel filtration }\end{array}$ & 0.58 & 543 & 936 & 11 & 195 \\
\hline \hline
\end{tabular}




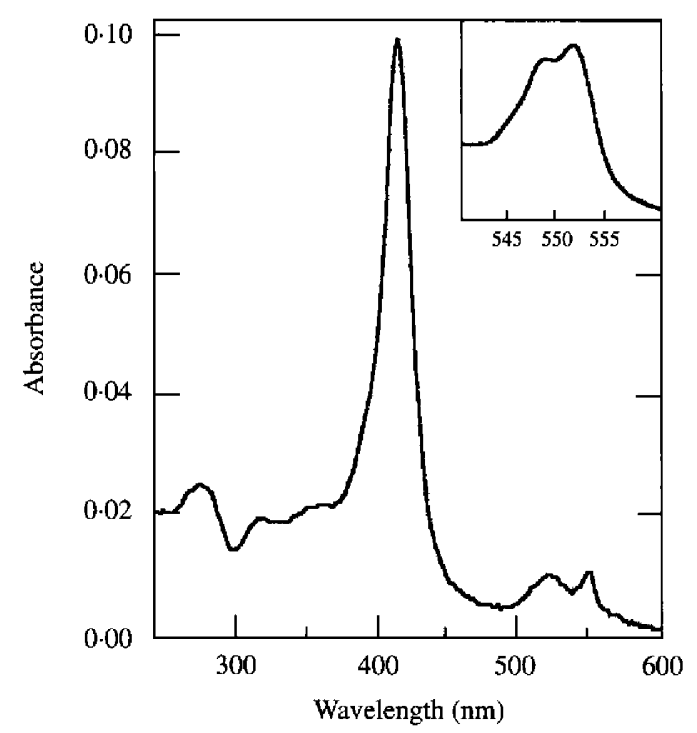

Fig. 1. Absorption spectrum of purified thiosulphate dehydrogenase. The spectrum was recorded from the eluent of gel filtration. The protein concentration in the peak fraction was $11 \mu \mathrm{g} \mathrm{ml}^{-1}$, as determined from the absorption ratio $A_{280} / A_{205}$ (Van Iersel et al., 1985). Inset: $77 \mathrm{~K}$ spectrum of the absorption peak at $553 \mathrm{~nm}$.

contained haem. A $77 \mathrm{~K}$ spectrum of purified thiosulphate dehydrogenase revealed a splitting of the $\alpha$ band, indicating that the native enzyme contains two different haem groups (Fig. 1).
Table 2. Electron acceptor specificity of thiosulphate dehydrogenase

Activities were determined using the standard enzyme assay.

\begin{tabular}{|c|c|c|}
\hline Electron acceptor & $\begin{array}{c}\text { Concn } \\
(\mathrm{mm})\end{array}$ & $\begin{array}{l}\text { Relative } \\
\text { activity } \\
(\%)\end{array}$ \\
\hline Ferricyanide & 0.9 & 100 \\
\hline $\begin{array}{l}\text { Cytochrome } c \text { (horse } \\
\text { heart) }\end{array}$ & 0.05 & $12 \cdot 1$ \\
\hline Wurster's blue & $0 \cdot 10$ & $12 \cdot 1$ \\
\hline $\begin{array}{l}\text { Cytochrome } c_{550} \\
\text { (Thiobacillus versutus) }\end{array}$ & 0.06 & $2 \cdot 5$ \\
\hline DCPIP/PMS & $0.05 / 0.6$ & 1.8 \\
\hline DCPIP/PES & $0.05 / 0.6$ & 1.6 \\
\hline
\end{tabular}

\section{Catalytic properties}

Stoichiometry. Incubation at $\mathrm{pH} 3 \cdot 0$ of purified thiosulphate dehydrogenase with $0.5 \mathrm{~mm}$-thiosulphate and ferricyanide resulted in a stoichiometric formation of tetrathionate (Fig. 2). Tetrathionate formation did not occur in the absence of enzyme.

Effect of $\mathrm{pH}$ on enzyme activity and stability. The enzyme exhibited maximum activity at $\mathrm{pH} 3.0$ (Fig. 3), where activity was approximately $30-$ fold higher than at $\mathrm{pH} 7 \cdot 0$. Below $\mathrm{pH} 2$, the enzyme activity rapidly decreased. The enzyme activity was not very stable. The

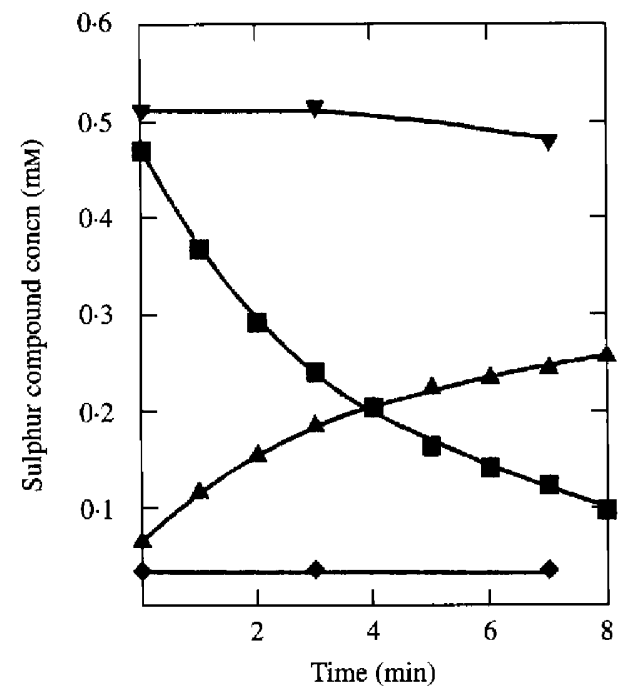

Fig. 2

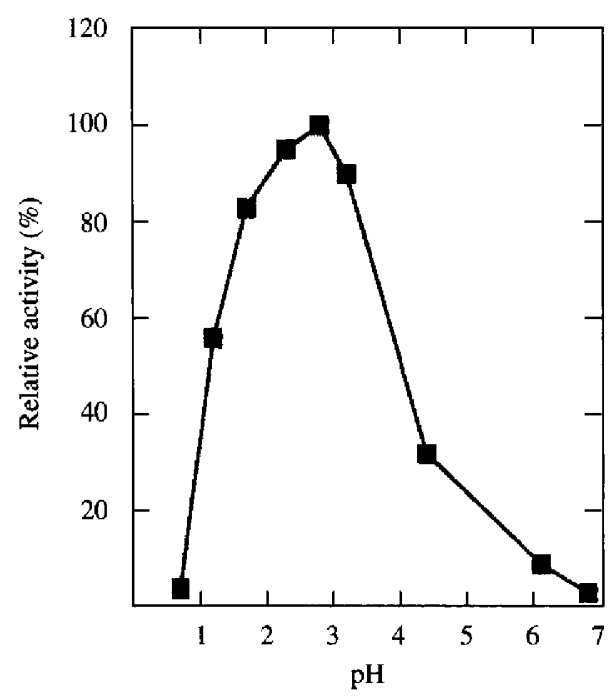

Fig. 3

Fig. 2. Reaction stoichiometry at $\mathrm{pH} 3 \cdot 0$. Formation of tetrathionate during incubation of $0.5 \mathrm{~mm}$-thiosulphate with purified enzyme at $\mathrm{pH} 3.0$ and $30^{\circ} \mathrm{C}$. Thiosulphate in the presence $(\boldsymbol{\square})$ and absence $(\boldsymbol{\nabla})$ of enzyme. Tetrathionate in the presence $(\boldsymbol{\Delta})$ and absence $(\boldsymbol{\Delta})$ of enzyme. The small amount of tetrathionate found in the absence of enzyme is due to slow cyanolysis of thiosulphate in the absence of cupric ions.

Fig. 3. Effect of $\mathrm{pH}$ on thiosulphate dehydrogenase activity. Activities were determined at $\mathrm{pH} 3 \cdot 0$ with $0 \cdot 2$ mM-thiosulphate in the enzyme assay. 
Table 3. Inhibition of thiosulphate dehydrogenase at pH 3.0

Activities were determined at $\mathrm{pH} 3.0$ with 0.2 mM-thiosulphate in the enzyme assay.

\begin{tabular}{llc}
\hline \hline & & Concn \\
Inhibitor & $\begin{array}{c}\text { Relative } \\
\text { activity } \\
(\%)\end{array}$ \\
\hline $\mathrm{None}$ & - & 100 \\
$\mathrm{Na}_{2} \mathrm{SO}_{3}$ & $0 \cdot 005$ & 27 \\
$\mathrm{~K}_{2} \mathrm{~S}_{4} \mathrm{O}_{6}$ & 5 & 64 \\
$\mathrm{Na}_{2} \mathrm{~S}_{3} \mathrm{O}_{6}$ & $0 \cdot 05$ & 47 \\
$\mathrm{Na}_{2} \mathrm{SeO}_{3}$ & $0 \cdot 5$ & 61 \\
$\mathrm{Na}_{2} \mathrm{SeO}_{4}$ & 5 & 49 \\
$\mathrm{NaHAsO}_{4}$ & $0 \cdot 5$ & 74 \\
$\mathrm{NaAsO}_{2}$ & $0 \cdot 5$ & 88 \\
$p-\mathrm{Chloromercuribenzoate}$ & $0 \cdot 1$ & 68 \\
$\mathrm{NaN}_{3}$ & $0 \cdot 5$ & 37 \\
\hline \hline
\end{tabular}

effect of $\mathrm{pH}$ on the stability of enzyme activity was studied at 0 and $30^{\circ} \mathrm{C}$. At both temperatures, the decrease in enzyme activity was not affected by the $\mathrm{pH}$ at which the enzyme was incubated $(\mathrm{pH} 1 \cdot 0-7 \cdot 0)$. At $30^{\circ} \mathrm{C}$, the enzyme activity decreased to $50 \%$ in $2 \mathrm{~h}$. At $0{ }^{\circ} \mathrm{C}$, $80 \%$ and $40 \%$ of the initial thiosulphate dehydrogenase activity was present after 2 and $7 \mathrm{~h}$, respectively. Enzyme frozen in liquid nitrogen was stable for at least 3 months.

Kinetic constants. At $\mathrm{pH} 7 \cdot 0$, a $K_{\mathrm{m}}$ for thiosulphate of $0.54 \mathrm{~mm}$ was calculated. From the specific activity of the purified enzyme at $\mathrm{pH} 7 \cdot 0$, a turnover number of $8500 \mathrm{~s}^{-1}$ could be calculated. The $K_{\mathrm{m}}$ for thiosulphate at the $\mathrm{pH}$ optimum could not be determined because of the chemical reactivity of thiosulphate at millimolar concentrations at $\mathrm{pH} 3$ (Roy \& Trudinger, 1970). Enzyme activity at this $\mathrm{pH}$ increased linearly with increasing thiosulphate concentration up to $0.2 \mathrm{~mm}$ (results not shown). Although this indicates that the enzyme activities, measured with $0.2 \mathrm{~mm}$-thiosulphate were suboptimal, they were over 30 -fold higher than the activities observed at $\mathrm{pH} 7.0$ with saturating substrate concentrations (Fig. 3). The maximum turnover number at $\mathrm{pH} 3.0$ may therefore be at least $250000 \mathrm{~s}^{-1}$.

Substrate and electron acceptor specificity. Thiosulphate-dehydrogenase-dependent reduction of ferricyanide at $\mathrm{pH} 3.0$ or $\mathrm{pH} 7.0$ was not observed with sulphite $(0.5 \mathrm{~mm})$, trithionate $(5 \mathrm{~mm})$ or tetrathionate $(5 \mathrm{~mm})$. At $\mathrm{pH} 7 \cdot 0$, several potential electron acceptors were tested. The enzyme activities with the different electron acceptors were not determined as a function of electron acceptor concentration. Therefore, they can be compared only qualitatively (Table 2). At higher concentrations of Wurster's blue and DCPIP, chemical interactions in the standard assay mixture prevented accurate activity measurements. Although activities were lower than with ferricyanide, horse heart cytochrome $c$ and Wurster's blue supported substantial activity. PMS and PES (assayed in the presence of DCPIP) and T. versutus cytochrome $c_{550}$ supported low, but significant enzyme activities (Table 2). No activity was detected with molecular oxygen, $\mathrm{NAD}^{+}, \mathrm{NADP}^{+}, \mathrm{PQQ}$, methyl- or benzyl viologen, methylene blue or MTT.

Inhibitor studies. The effect of potential inhibitors of enzyme activity was tested at $\mathrm{pH} 3.0$. At micromolar concentrations, sulphite was a potent inhibitor (Table 3). Inhibition of enzyme activity by sulphite did not follow saturation kinetics, but was linear with the sulphite concentration (data not shown). The sulphite-analogue selenite also inhibited enzyme activity (Table 3). Other compounds which negatively affected enzyme activity included the polythionates tetrathionate and trithionate, selenate, azide and relatively high concentrations of the

Table 4. Properties of thiosulphate dehydrogenases from Thiobacillus species

\begin{tabular}{|c|c|c|c|c|c|c|}
\hline Organism & $\begin{array}{l}\text { Mol. } \\
\text { mass } \\
(\mathrm{kDa})\end{array}$ & $\begin{array}{l}K_{\mathrm{m}}^{*} \\
(\mathrm{mM})\end{array}$ & $\begin{array}{l}\text { Observed } V_{\max }^{\dagger} \\
{\left[\mathrm{U}(\mathrm{mg} \text { protein })^{-1}\right]}\end{array}$ & Prosthetic group & Artificial electron acceptors $\ddagger$ & Reference \\
\hline T. neapolitanus & NI & 1 & $\begin{array}{c}3100(\mathrm{pH} 4 \cdot 5)^{a} \\
100(\mathrm{pH} 7)\end{array}$ & NI & $\begin{array}{c}\mathrm{K}_{3} \mathrm{Fe}(\mathrm{CN})_{6}, \text { Cytochrome } \\
c_{553.5}{ }^{a}\end{array}$ & Trudinger (1961) \\
\hline T. thioparus & 115 & $0 \cdot 1$ & $\begin{array}{l}220(\mathrm{pH} 45)^{a} \\
170(\mathrm{pH} 7)\end{array}$ & Non-haem iron & $\mathrm{K}_{3} \mathrm{Fe}(\mathrm{CN})_{6}$, Cytochrome $c^{b}$ & $\begin{array}{l}\text { Lyric \& Suzuki } \\
(1970)\end{array}$ \\
\hline T. tepidarius & 138 & $0 \cdot 1$ & $315(\mathrm{pH} \mathrm{7})$ & No haem detected & $\mathrm{K}_{3} \mathrm{Fe}(\mathrm{CN})_{6}$, Cytochrome $c^{b}$ & Lu \& Kelly (1988) \\
\hline T. ferrooxidans & NI & $0 \cdot 9$ & $\begin{array}{c}2250(\mathrm{pH} 5)^{b} \\
350(\mathrm{pH} 7)\end{array}$ & NI & $\mathrm{K}_{3} \mathrm{Fe}(\mathrm{CN})_{6}{ }^{c}$ & $\begin{array}{l}\text { Silver \& Lundgren } \\
(1968)\end{array}$ \\
\hline T. acidophilus & 102 & 0.5 & $\begin{array}{c}>150000(\mathrm{pH} \mathrm{3})^{b, c} \\
4900(\mathrm{pH} 7)\end{array}$ & Cytochrome $c_{553}$ & $\begin{array}{l}\mathrm{K}_{3} \mathrm{Fe}(\mathrm{CN})_{6}, \text { Wurster's blue, } \\
\text { Cytochrome } c^{b}, \\
\text { Cytochrome } c_{550}{ }^{d}\end{array}$ & This study \\
\hline
\end{tabular}

$* K_{\mathrm{m}}$ for thiosulphate with $\mathrm{K}_{3} \mathrm{Fe}(\mathrm{CN})_{6}$ as electron acceptor

$\dagger \mathrm{K}_{3} \mathrm{Fe}(\mathrm{CN})_{5}$ as electron acceptor: $a$, lowest $\mathrm{pH}$ value used; $b, \mathrm{pH}$ optimum; $c$, non-saturating substrate concentration.

$\ddagger a$, Native cytochrome $c_{553.5} ; b$, horse heart cytochrome $c ; c$, no activity with horse heart cytochrome $c$ as electron acceptor; $d$, cytochrome $c_{550}$ from $T$. versutus.

NI, Not investigated. 
sulphydryl-binding agents sodium arsenate, sodium arsenite and $p$-chloromercuribenzoate. No inhibition was observed with the chelating agents citrate and EDTA, nor with $N$-ethylmaleimide.

\section{Discussion}

Thiosulphate dehydrogenase activity has been studied in a number of acidophilic and neutrophilic thiobacilli (Table 4). This paper represents the first successful attempt to purify this enzyme to apparent homogeneity. From a comparison of structural and catalytic properties of thiosulphate dehydrogenases from various Thiobacillus species (Table 4 ), it appears that there are very few conserved features. This observation is compatible with the genetic heterogeneity of the genus Thiobacillus, as evident from 16S RNA sequence data (Lane et al., 1992).

The absorption spectrum of the purified thiosulphate dehydrogenase described here clearly indicates the presence of a haem moiety (Fig. 1). In contrast, no haem could be detected in partially purified thiosulphate dehydrogenases from $T$. tepidarius (Lu \& Kelly, 1988) and $T$. thioparus (Lyric \& Suzuki, 1970). Instead, in the latter organism, involvement of non-haem iron was suggested. A tetrameric conformation, containing two moles of each subunit per mole of enzyme, represents the best match for the molecular mass of the native thiosulphate dehydrogenase $(102 \mathrm{kDa})$ and that of the two subunits ( 24 and $20 \mathrm{kDa}$ ). This is consistent with the observations that both subunits contain haem and that the calculated cytochrome content was 5.3 moles of haem per mole of native enzyme. The low yields of purified protein prevented us from investigating the presence of other redox-centres.

As was shown for thiosulphate dehydrogenase from $T$. thioparus (Lyric \& Suzuki, 1970), sulphite was a very potent inhibitor of enzyme activity (Table 3). Inhibition of enzyme activity was linear with sulphite concentration. Thiosulphate oxidation by intact cells of $T$. acidophilus is only inhibited by sulphite concentrations above $0.2 \mathrm{~mm}$. At lower concentrations, thiosulphate and sulphite are simultaneously oxidized to sulphate (results not shown).

The low $\mathrm{pH}$ optimum of thiosulphate dehydrogenase from $T$. acidophilus (Fig. 3) is consistent with its supposed localization in the periplasm (Meulenberg et al., $1992 a$; Pronk et al., 1990 a). The ability of the purified enzyme to use horse heart cytochrome $c$ and a bacterial $c$-type cytochrome as electron acceptor at $\mathrm{pH} 7 \cdot 0$ (Table 2) implies that the physiological electron acceptor may be a $c$-type cytochrome. Coupling of thiosulphate oxidation to the respiratory chain at the level of cytochrome $c$ would be compatible with a periplasmic localization and with the observed growth efficiencies in mixotrophic chemostat cultures (Pronk et al., 1990c). It is not yet clear which cytochrome $c$ is involved as analysis of cytochrome spectra of intact cells of $T$. acidophilus has revealed the presence of at least five different $c$-type cytochromes (J. T. Pronk \& J. E. van Wielink, unpublished).

The authors are grateful to Cornel Verduyn for many stimulating discussions. We thank Marten Hazelaar for recording the $77 \mathrm{~K}$ spectra, Barend Groen for help with the photodiode array detector and Ton Mulder for providing us with a sample of purified cytochrome $c_{550}$ from $T$. versutus and for help with the gel electrophoresis. Marijke Luttik is acknowledged for preparation of Fig. 1.

\section{References}

Bartsch, R. G. (1971). Cytochromes: bacterial. Methods in Enzymology 23, 344-363.

BRADFORD, M.M. (1976). A rapid and sensitive method for the quantitation of microgram quantities of protein utilizing the principle of protein-dye binding. Analytical Biochemistry 72, 248-254.

Gorenstein, M. V., Li, J. B. \& Chapman, D. (1993). Abstract no. 974, Pittsburgh Conference, Atlanta, USA.

LAEMMLI, U. K. (1970). Cleavage of structural proteins during the assembly of the head of bacteriophage T4. Nature, London 227 $680-685$.

Lane, D. J., Harrison, A. P., Jr, Stahl, D., Pace, B., Grovannoni, S. J., OLsen, G. J. \& PACE, N. R. (1992). Evolutionary relationships among sulfur- and iron-oxidizing eubacteria. Journal of Bacteriology 174, 269-278.

Lu, W.-P. \& Kelly, D. P. (1988). Cellular location and partial purification of the 'thiosulphate-oxidizing enzyme' and 'trithionate hydrolase' from Thiobacillus tepidarius. Journal of General Microbiology 134, 877-885.

LYRIC, R. M. \& SUZUKI, I. (1970). Enzymes involved in the metabolism of thiosulfate by Thiobacillus thioparus. III. Properties of thiosulfateoxidizing enzyme and proposed pathway of thiosulfate oxidation. Canadian Journal of Biochemistry 48, 355-363.

Meulenberg, R., Pronk, J. T., Hazeu, W., Bos, P. \& Kuenen, J. G. (1992a). Oxidation of reduced sulphur compounds by intact cells of Thiobacillus acidophilus. Archives of Microbiology 157, 161-168.

Meulenberg, R., Pronk, J. T., Frank, J., Hazed, W., Bos, P. \& KuENEN, J. G. (1992b). Purification and partial characterization of a thermostable trithionate hydrolase from the acidophilic sulphur oxidizer Thiobacillus acidophilus. European Journal of Biochemistry 209, 367-374.

Michaelis, L. \& Gramick, S. (1943). The polymerization of the free radicals of the Wurster dye type: the dimeric resonance band Journal of the American Chemical Society 65, 1747-1755.

OkuZumI, M. \& KrTa, Y. (1965). Studies on biochemistry of the thiobacilli. VI. Oxidation of thiosulphate to tetrathionate by $T$. thiooxidans. Agricultural and Biological Chemistry 29, 1063-1068.

Pronk, J. T., Meulenberg, R., Hazeu, W., Bos, P. \& Kuenen, J. G. (1990a). Oxidation of reduced inorganic sulphur compounds by acidophilic thiobacilli. FEMS Microbiology Reviews 75, 293-306.

Pronk, J. T., Mresters, P. J. W., van Dijken, J. P., Bos, P. \& Kuenen, J. G. $(1990 \mathrm{~b})$. Heterotrophic growth of Thiobacillus acidophilus in batch and chemostat cultures. Archives of Microbiology 153, 392-398.

Pronk, J. T., Meulenberg, R., van den BerG, D. J. C., Batenburgvan der Vegte, W., Bos, P. \& Kuenen, J. G. (1990 c). Mixotrophic and autotrophic growth of Thiobacillus acidophilus on glucose and thiosulfate. Applied and Environmental Microbiology 56, 3395-3401.

RIESKE, J. S. (1967). The quantitative determination of mitochondrial hemoproteins. Methods in Enzymology, 10, 488-493.

RoY, A. B. \& TRUDINGER, P. A. (1970). The Biochemistry of Inorganic Compounds of Sulphur. Cambridge: University Press.

Silver, M. \& LundGren, D. G. (1968). The thiosulfate-oxidizing enzyme of Ferrobacillus ferrooxidans (Thiobacillus ferrooxidans). Canadian Joumal of Biochemistry 46, 1215-1220. 
SINHA, D. B. \& WALDEN, C. C. (1966). Formation of polythionates and their interrelationships during oxidation of thiosulphate by $T$. ferrooxidans. Canadian Journal of Microbiology 12, 1041-1054.

Sö́вв, B. (1957). A colorimetric method for the determination of thiosulphate. Biochimica et Biophysica Acta 23, 412-416.

Thomas, P. E., Ryan, D. \& Levin, W. (1976). An improved staining procedure for the detection of the peroxidase activity of cytochrome P450 on sodium dodecyl sulfate polyacrylamide gels. Analytical Biochemistry 75, 168-176.
TRUdinger, P. A. (1961). Thiosulphate oxidation and cytochromes in Thiobacillus X. Biochemical Journal 78, 680-686.

VAN IERSEL, J., Frank JZN, J. \& DUINE, J. A. (1985). Determination of absorption coefficients of purified proteins by conventional ultraviolet spectrophotometry and chromatography combined with multiwavelength detection. Analytical Biochemistry 151, 196-204.

WooD, A. P. \& KELLY, D. P. (1986). Chemolithotrophic metabolism of the newly-isolated moderately thermophilic, obligately autotrophic Thiobacillus tepidarizs. Archives of Microbiology 144, 71-77. 